\title{
PENEGAKAN HUKUM MAHAR POLITIK DALAM PILPRES 2019 DITINJAU DARI POLITIK HUKUM PIDANA
}

\author{
Irwan Hafid \\ Magister IImu Hukum Universitas Islam Indonesia \\ Jl. Cik Ditiro No. 1 Yogyakarta \\ irwan.hafidz@gmail.com \\ Dendy Prasetyo Nugroho \\ Pusat Studi Kejahatan Ekonomi Fakultas Hukum Universitas Islam Indonesia \\ Jl. Taman Siswa No. 158 Yogyakarta \\ dendyprasetyonugroho90@gmail.com
}

\begin{abstract}
The issue of political dowry, relatively, becomes a sustainable warning of problems in every general election in Indonesia. Such as the issue of Sandiaga Uno, who provided political dowry in the 2019 presidential election. The allegation was started by the Deputy of General-secretary of the Party of Democrat, Andi Arief, who stated that Sandiaga Uno had provided 500 billion rupiahs to PAN and PKS respectively so that those two parties would support him to nominate as the Candidate of Vice President for Prabowo Subianto. Political dowry has been a serious issue and almost constantly becomes an interesting topic to be reported and studied in every general election. Although it is popular, the issue of political dowry is a case that is relatively difficult to prove its truth (court decisions). In fact, explicitly, political dowry has been regulated in Article 228 on Law Number 7 of 2017 concerning the General Election (Election Law). However, it does not expressly provide a deterrent effect to the political dowry actors. This reality becomes the basis of encouragement in conducting this research. The theory used in this research is legal politics and law enforcement. While the method used is normative legal research with a statutory, conceptual, and comparative approach. The output of this paper is that the handling of political dowry cases in the presidential election needs a serious concern. And then, the regulation on sanctions, which still be administrative in nature, against the actors of political dowry in the
\end{abstract}


Election Law is considered to be inappropriate. So that criminal policy is needed to strengthen the law enforcement and strict legal instruments against criminal acts of political dowry in the future election (ius constituendum)

Keywords: election, dowry, politics, sanction, criminal

\begin{abstract}
Abstrak
Isu mahar politik relatif menjadi catatan permasalahan yang terus berkelanjutan dalam setiap pelaksanaan pemilihan umum di Indonesia. Seperti halnya isu pemberian mahar politik Sandiaga Uno dalam pemilihan umum presiden tahun 2019. Dugaan tersebut bermula dari cuitan twitter Wakil Sekretaris Jendral Partai Demokrat, Andi Arief, yang menyatakan bahwa Sandiaga Uno diduga telah memberikan uang sebesar masingmasing Rp. 500 Miliar kepada PAN dan PKS, agar kedua partai tersebut mendukungnya maju sebagai Calon Wakil Presiden Prabowo Subianto. Mahar politik merupakan persoalan serius dan hampir selalu menjadi topik pemberitaan dan kajian yang menarik dalam setiap pemilu. Meskipun mahar politik termasuk isu populer, persoalan mahar politik merupakan kasus yang relatif susah untuk dibuktikan dalam ranah hukum (putusan pengadilan). Padahal secara eksplisit, mahar politik telah diatur dalam Pasal 228 Undang-Undang Nomor 7 Tahun 2017 tentang Pemilihan Umum (UU Pemilu). Namun hal tersebut tidak secara tegas memberikan efek jera terhadap pelaku mahar politik. Realitas tersebut kiranya menjadi basis dorongan dilakukannya penulisan ini. Teori yang digunakan dalam penelitian ini ialah teori politik hukum dan penegakan hukum. Sementara metode yang digunakan adalah penelitian hukum normatif dengan pendekatan perundang-undangan (statue approach), pendekatan konsep (conceptual approach), dan pendekatan perbandingan (comparative approach). Adapun output dari tulisan ini, bahwa penanganan terhadap kasus mahar politik dalam pemilihan umum presiden perlu menjadi perhatian serius. Selain itu, pengaturan sanksi yang hanya bersifat administratif terhadap pelaku mahar politik dalam UU Pemilu dinilai kurang tepat. Sehingga kedepan diperlukan politik hukum pidana dalam memperkuat penegakan hukum dan instrumen hukum yang tegas dan lugas terhadap tindak pidana mahar politik pada pemilu yang akan datang (ius constituendum).
\end{abstract}

Kata Kunci: pemilu, mahar, politik, sanksi, pidana 


\section{Pendahuluan}

Penelitian ini dilatarbelakangi oleh empat urgensi permasalahan. Pertama, salah satu ciri umum negara yang menganut sistem demokrasi ialah ditandai dengan adanya pemilu. Dengan pemilu rakyat dapat menjalankan kedaulatannya secara utuh (Pasal 1 ayat (2) UUD NRI 1945). Namun implementasi kedaulatan tersebut tidak sepenuhnya dapat terealisasi. Sebab mobilisasi partai politik terkadang lebih mendominasi dalam memegang peranan kedaulatan rakyat. Kemampuan finansial (financial capability) kandidat calon pemimpin justru dijadikan salah satu tolak ukur bagi partai politik untuk memilih kandidat yang ingin dicalonkan. Akibatnya, kedaulatan rakyat secara tidak langsung terdegradasi oleh kedaulatan finansial dari kalangan pemodal tersebut. Sehingga, visi, misi, serta kualitas pengalaman para calon bisa dikatakan bukanlah satu-satunya parameter utama dalam menentukan seorang pemimpin.

Kedua, dalam setiap pelaksanaan kontestasi politik, baik dalam pilkada maupun pemilu, Isu mahar politik hampir selalu menjadi topik yang menarik untuk diberitakan kepada publik. Seperti halnya dugaan pemberian mahar politik sebesar masing-masing Rp. 500 miliar dari Sandiaga Uno, kepada Partai Amanat Nasional (PAN) dan Partai Keadilan Sejahtera (PKS), agar kedua partai bersedia mendukungnya maju sebagai Calon Wakil Presiden pendamping Prabowo Subianto dalam Pilpres 2019 (Nainggolan, 2018). Beberapa kasus lain juga pernah mencuat di media, diantaranya kasus mahar politik dalam pilkada serentak 2018 yang melibatkan Siswandi dalam pilkada Kota
Cirebon, Yan Mandenas dalam pilkada Papua, La Nyalla Mattalitti dalam pilkada Jawa Timur, dan Jhon Krisli dalam pilkada Palangkaraya (Vionita \& Khasanah, 2018). Ketiga, secara regulasi, aturan terkait mahar politik ternyata masih menyisakan permasalahan mendasar yang harus segera dituntaskan. Substansi problem mahar politik ini, bermula dari kurang komprehensifnya UU Pemilu mengatur terkait sanksi pidana pemilu. Artinya, UU Pemilu hanya memberi sanksi yang bersifat administratif terhadap pelanggaran mahar politik (Pasal 228). Disisi lain, regulasi mahar politik dalam UU Pemilu ternyata inkonsisten dengan rumusan mahar politik dalam UU No. 10 Tahun 2016 tentang Perubahan Kedua atas UU No. 10 Tahun 2015 tentang Penetapan Perppu No. 1 Tahun 2014 tentang Pemilihan Gubernur, Bupati, dan Walikota menjadi Undang-Undang (UU Pilkada). Sebab dalam pasal 47 juncto pasal 187B-187C UU Pilkada, justru diatur secara tegas terkait sanksi pelanggaran pidana mahar politik, baik administratif, denda, maupun pidana bagi pemberi dan penerima mahar politik.

Keempat, penegakan hukum terhadap mahar politik seringkali terkendala karena rumitnya dalam pembuktian. Sehingga isu mahar politik seringkali muncul, namun tenggelam tanpa penjelasan kronologi secara utuh kepada publik. Bahkan dari sekian banyak isu mahar politik, hingga saat ini belum ada satupun kasus yang berhasil dilanjutkan ke ranah hukum (Utama, 2018). Seperti kasus Sandiaga Uno yang berakhir di Bawaslu karena dinilai tidak terbukti secara hukum, kasus La Nyalla Mattalitti diberhentikan oleh Bawaslu karena yang bersangkutan tidak pernah menghadiri panggilan untuk 
memberi keterangan atau mengadukan kasusnya kepada Bawaslu (Nugraheny, 2018). Bahkan dalam kasus mahar politik yang melibatkan Jhon Krisli, harus berakhir karena Panwaslu Palangkaraya kalah voting dalam menentukan cukup tidaknya alat bukti pada saat pembahasan di Gakkumdu (Karana, 2018). Padahal yang bersangkutan mengaku sudah pernah dimintai mahar oleh salah satu partai politik yang mengusungnya.

Berangkat dari uraian tersebut, maka penulisan ini dimaksudkan untuk menganalisis bagaimana realitas penegakan hukum tindak pidana mahar politik serta bagaimana rumusan kebijakan atau politik hukum pidana terhadap tindakan mahar politik dalam UU Pemilu di Indonesia. Adapun tujuan dari penulisan naskah ini, secara teoritis diharapkan dapat memberikan uraian yang utuh mengenai konsep politik hukum pidana terhadap tindakan mahar politik dalam UU Pemilu serta penegakan hukumnya kedepan. Sedangkan secara praktis, tulisan ini diharapkan dapat menjadi bahan referensi dan penelitian lebih lanjut oleh akademisi, penyelenggara pemilu, para penggiat anti korupsi, serta masyarakat pada umumnya.

\section{Metode Penelitian}

Penelitian ini merupakan penelitian hukum normatif yang mengkaji politik hukum pidana serta praktek penegakan hukum tindak pidana mahar politik di Indonesia. Bahan hukum yang digunakan adalah bahan hukum primer, bahan hukum sekunder, serta bahan hukum tersier. Sementara pendekatan yang digunakan ialah pendekatan perundangundangan (statute approach), pendekatan konsep (conseptual approach), dan pendekatan perbandingan (comparative approach). Kemudian bahan hukum dikumpulkan dengan dua cara, yakni studi dokumen dan studi literatur yang terkait dengan mahar politik di Indonesia. Setelah itu, temuan hasil penelitian yang diperoleh dari ketiga bahan hukum di atas, selanjutnya dianalisis secara deskriptif kualitatif melalui tiga alur kegiatan, yakni reduksi bahan hukum, penyajian bahan hukum, serta penarikan kesimpulan.

\section{Perspektif Teori}

\subsection{Teori Penegakan Hukum}

Penegakan hukum dapat dirumuskan sebagai suatu usaha untuk melaksanakan hukum sebagaimana mestinya, mengawasi pelaksanaanya, serta memulihkan hukum supaya ditegakkan kembali (Rahmanto, 2019). Lebih lanjut Satjipto Rahardjo menegaskan, bahwa penegakan hukum merupakan satu usaha untuk mewujudkan ide atau konsep hukum menjadi kenyataan (Rahardjo, 2009). Ide atau konsep tersebut merupakan pikiran-pikiran badan pembuat undangundang yang dirumuskan dalam bentuk peraturan-peraturan hukum.

Sementara Peter Mahmud Marzuki memaknai penegakan hukum sebagai suatu usaha untuk mewujudkan ide-ide tentang keadilan dan kepastian dalam hukum (Marzuki, 2012). Dari beberapa pendapat tersebut dapat dipahami bahwa penegakan hukum merupakan upaya yang bertujuan untuk meningkatkan ketertiban serta kepastian hukum dalam masyarakat. Dimana hal tersebut dapat dilakukan dengan menertibkan fungsi, tugas dan wewenang lembaga-lembaga yang bertugas menegakkan hukum menurut 
proporsi, ruang lingkup, serta sistem yang dapat mendukung tujuan yang hendak dicapai oleh hukum (Roihanah, 2015).

Dalam praktek penegakannya, hukum sering kali bersinggungan bahkan tarikmenarik dengan kepentingan diluar hukum, seperti halnya kepentingan antara politik dan hukum. Dalam pandangan Satjipto Rahardjo (1996) politik seringkali tampak memiliki konsentrasi energi yang lebih dominan terhadap hukum, sehingga politik sangat menentukan bekerjanya hukum, bahkan penegakan hukum. Sementara disisi yang lain, Marc Galanter berpendapat bahwa jika dilihat dari kenyataan lapangan, penegakan hukum merupakan sesuatu yang kompleks sehingga hal tersebut juga perlu dilihat dari sudut lain (Galanter, 1974).

Dalam bahasa Lawrence M. Friedman, memamahi hukum, termasuk memahami penegakan hukum harus diletakkan dalam konteks sistem hukum, diantaranya struktur hukum (legal structure), substansi hukum (legal substance), dan kultur atau budaya hukum (legal culture) (Friedman, 1986). Struktur hukum, yaitu kelembagaan yang diciptakan oleh sistem hukum dengan berbagai macam fungsi untuk mendukung bekerjanya sistem hukum. Substansi hukum, merupakan aturan atau materi hukum. Sementara budaya hukum adalah nilai dan sikap yang mempengaruhi tegaknya atau bekerjanya hukum, baik kultur internal (penegak hukum) maupun kultur eksternal (budaya masyarakat).

Oleh sebab itu, menerima hukum begitu saja tanpa mengamati kenyataan tentang bagaimana sesungguhnya pesan dan kemauan hukum itu dijalankan, sama artinya dengan membuat mitos tentang hukum (Chambliss \& Siedman, 1971).
Sehingga dalam penegakan hukum, juga harus diperhatikan variabel-variabel lain yang terkait, seperti faktor manusia, institusi, politik, budaya, dan hukum itu sendiri. Sebab hukum bukan hanya untuk dirinya sendiri, melainkan untuk sesuatu yang lebih luas, yaitu untuk harga diri manusia, kebahagiaan, dan kesejahteraan masyarakat pada umumnya.

\subsection{Teori Politik Hukum}

Uraian tentang politik hukum sudah banyak didefinisikan oleh para ahli dalam berbagai literatur. Moh. Mahfud M.D, mendefinisikan politik hukum sebagai legal policy atau garis kebijakan resmi tentang hukum yang akan diberlakukan, baik dengan pembuatan hukum baru maupun dengan penggantian hukum lama, dalam rangka mencapai tujuan negara (Mahfud, 2012). Sedangkan menurut Sudarto, politik hukum merupakan upaya untuk mewujudkan peraturan-peraturan yang baik sesuai dengan keadaan dan situasi pada suatu waktu (Sudarto, 2007). Berangkat dari pengertian tersebut, maka substansi politik hukum pada dasarnya: Pertama, merupakan kebijakan resmi suatu negara dalam menetapkan hukum yang akan diberlakukan saat ini (ius constitutum). Kedua, kebijakan tersebut juga berhubungan dengan hukum yang dicita-citakan (ius constituendum). Ketiga, politik hukum bertujuan mewujudkan peraturan yang lebih baik dalam mengatur kehidupan berbangsa dan bernegara.

Dalam perspektif hukum pidana, Peter Hoefnagels menggunakan istilah politik hukum pidana (criminal policy) untuk merespon pentingnya perubahan hukum dalam konteks pencegahan kejahatan. Dalam konteks ini, istilah politik hukum pidana disebut sebagai 
the rational organization of the social reactions to crime (Hoefnagels, 1973). Atau dalam istilah lain, Hoefnagels (1973) juga memaknai sebagai a policy of designating human behavior as crime or criminal policy is the science of crime prevention.

Sebagai bagian dari politik hukum, Sudarto (1986) menyebut bahwa politik hukum pidana juga mengandung arti, bagaimana membuat dan merumuskan suatu aturan hukum pidana yang baik, yang akan diberlakukan dalam suatu waktu tertentu guna memenuhi keadilan dalam masyarakat. Sementara menurut Marc Ancel, politik hukum pidana merupakan suatu ilmu sekaligus seni yang mempunyai tujuan praktis untuk memungkinkan peraturan hukum positif dirumuskan secara lebih baik agar dijadikan pedoman, baik oleh pembuat undang-udang, pengadilan, serta para penyelenggara atau pelaksana putusan pengadilan (Arief, 1992).

Bertalian dengan itu, Mulder berpendapat bahwa substansi politik hukum pidana (strafrechts politiek) ialah garis kebijakan untuk: Pertama, seberapa jauh ketentuan-ketentuan pidana yang berlaku perlu diubah atau diperbaharui. Kedua, apa yang dapat diperbuat untuk mencegah terjadinya tindak pidana. Ketiga, cara bagaimana penyidikan, penuntutan, peradilan dan pelaksanaan pidana dilaksanakan (Hamdan, 1999).

Berdasarkan uraian tersebut, Sudarto (2007) menegaskan bahwa inti dari politik hukum pidana ialah perbuatan apa yang tepat untuk dijadikan tindak pidana, sanksi apa yang seharusnya dikenakan terhadap pelanggar ketentuan pidana, serta bagaimana prosedur yang harus ditempuh agar pelaku dapat dikenai sanksi pidana. Kaitannya dengan politik hukum pidana terhadap tindakan mahar politik di Indonesia, maka akan dilihat rumusan perbuatan, sanksi, hingga prosedur hukum yang akan diberlakukan dalam aturan mahar politik kedepan (ius constituendum).

\section{Hasil Dan Pembahasan}

\subsection{Penegakan Hukum Tindak Pidana Mahar Politik dalam Pilpres 2019}

Istilah mahar politik secara umum dapat dimaknai sebagai transaksi di bawah tangan (illicit deal) dari calon yang diusung kepada partai politik agar bersedia menjadi perahu dalam memperebutkan jabatan politik (elected office) (Azra, 2016). Mahar politik tidak ditemukan dalam kamus perundangundangan, sebab istilah ini secara implisit hanya dipadankan dengan frasa imbalan dalam UU Pemilu, dimana aturan tersebut masih menyisakan problem mendasar hingga saat ini. Padahal praktik mahar politik sangat mencederai nilai demokrasi serta merupakan benih-benih munculnya praktik korupsi. Bahkan rasanya tidak berlebihan jika dikatakan bahwa calon yang terpilih melalui mahar politik (political dowry) dan/atau politik uang suatu saat akan melakukan korupsi politik demi untuk menutupi tingginya modal pencalonan yang tidak wajar atau mahar politik (Yusfitriadi, 2018).

\section{- $\quad$ Aspek Hukum Mahar Politik}

Konsep pengaturan tindak pidana mahar politik telah diatur dalam pasal 228 UU Pemilu, yang menyatakan bahwa parpol dilarang menerima imbalan dalam bentuk apa pun pada proses pencalonan presiden dan wakil presiden. Larangan sebagaimana dimaksud juga berlaku 
secara mutatis mutandis terhadap seleksi calon anggota DPR, DPRD provinsi, dan DPRD kabupaten/kota (Pasal 242). Jika hal tersebut dilanggar, maka parpol yang bersangkutan secara administratif dilarang untuk mengajukan calon pada periode berikutnya (Pasal 228 ayat (2)). Jika ditelusuri lebih lanjut dalam pasalpasal yang mengatur tindak pidana pemilu (Pasal 488-554 UU Pemilu), ada sekitar 66 pasal yang mengatur subjek, objek, denda, dan masa hukuman yang dianggap melanggar kepastian hukum dan keadilan dalam Pemilu. Sayangnya, dalam aturan tersebut tidak ditemukan pasalpasal yang mengeksplorasi lebih jauh terkait mahar politik. Bertalian dengan itu, pasal yang mendekati ialah pasal 525 UU Pemilu, yang mengatur ancaman pidana bagi orang yang memberikan sumbangan dana melebihi batas yang sudah ditentukan.

Dalam konteks mahar politik, sumbangan dana kampanye tidak serta merta dapat diidentifikasi sebagai mahar politik. Karena sumbangan dana kampanye telah tegas diatur dalam pasal $327 \mathrm{UU}$ Pemilu. Dimana sumbangan perorangan dibatasi hingga 2,5 milyar dan perusahaan hingga 25 milyar. Jika melanggar diancam pidana penjara hingga dua tahun (Pasal 525). Secara praktis, pasal 525 UU Pemilu tidak bisa dikorelasikan terhadap pasal 228 UU Pemilu. Karena sumbangan dana kampanye telah secara legal diatur oleh UU Pemilu, sementara legalitas dan rumusan terkait mahar politik masih belum secara komprehensif diatur dalam UU Pemilu.

Jika ketentuan mahar politik dalam UU Pemilu dibandingan dengan mahar politik dalam rumusan UU Pilkada, maka terdapat inkonsistensi aturan yang sangat mendasar. Dalam pasal 47 juncto pasal 187B dan 187C UU Pilkada, telah diatur tegas terkait rumusan tindak pidana mahar politik, dimana pemberi dan penerimanya dapat dijatuhi sanksi, baik sanksi secara administratif, denda, maupun pidana. Sementara UU Pemilu hanya mengatur sanksi administratif bagi penerimanya saja.

Dengan demikian, rumusan mahar politik dalam UU Pemilu menunjukkan kelemahan regulasi dibandingkan UU Pilkada, diantaranya: Pertama, tidak ada sanksi yang tegas dan jelas terhadap pemberi mahar politik, kecuali terhadap penerima. Kedua, hanya diatur sanksi administratif, tanpa sanksi pidana. Ketiga, sanksinya bersifat percuma, karena tidak dapat langsung diberlakukan kecuali dalam pemilu berikutnya. Larangan tanpa sanksi yang tegas, cenderung tidak dapat memberi manfaat apa-apa dalam menjamin lahirnya pemimpin bangsa yang berintegritas dan berkualitas dari hasil pemilu.

\section{- Penegakan Hukum Mahar Politik}

Berdasarkan data Bawaslu, bahwa dari 514 kabupaten/kota di 34 provinsi di Indonesia memiliki konteks sosial politik masyarakat dengan tingkat kerawanan pelanggaran pemilu yang bervariasi. Dalam konteks mahar politik, jika dinilai dari adanya laporan atau temuan Bawaslu tentang praktik mahar politik, maka angka kerawanan mahar politik berada di angka $46,53 \%$. Sementara jika dilihat dari adanya pemberitaan media massa, maka tingkat kerawanan mahar politik berada di angka 38,11\% (Bawaslu, 2018). Selain itu, berdasarkan hasil survei KPK ditemukan bahwa 20 responden mengakui telah mengeluarkan biaya mahar antara $\mathrm{Rp}$. 
50 - 500 juta, per kursi, dalam kontestasi Pilkada Serentak 2018 (Dalilah, 2018). Meskipun demikian, penegakan hukum terhadap praktik mahar politik seringkali masih terkedala dengan sulitnya pembuktian. Seperti halnya dalam kasus yang diduga melibatkan Sandiaga Uno. Kasus tersebut berawal dari cuitan twitter Wasekjen Partai Demokrat, Andi Arief yang menyatakan bahwa PAN dan PKS diduga menerima uang masingmasing sebesar 500 miliar sebagai mahar politik, agar kedua partai bersedia mendukung Sandiaga Uno sebagai calon wakil presiden Prabowo Subianto. Peristiwa ini kemudian dilaporkan oleh Frits Bramy Daniel kepada Bawaslu pada 14 Agustus 2018.

Laporan dengan nomor: 01/LP/PP/ RI/ 00.00/VIII/2018 tersebut kemudian di proses oleh Bawaslu pada 16 Agustus 2018 karena diduga telah melanggar pasal 228 ayat (1) dan ayat (4) UU Pemilu. Sesuai ketentuan Pasal 18 Perbawaslu Nomor 7 Tahun 2018, maka Bawaslu kemudian melakukan kajian awal berupa klarifikasi terhadap para saksi, yaitu Frits Bramy Daniel, Ade Ardiansyah Utama, Steven Gleen Tunas, dan Andi Arief. Dari semua saksi, hanya Andi Arief yang tidak dapat dimintai keterangan. Selain itu, Bawaslu juga melakukan koordinasi dengan Bareskrim untuk mendiskusikan perihal klasifikasi dugaan mahar politik tersebut. Tetapi Bareskrim menilai bahwa kasus tersebut tidak dapat diproses secara pidana karena pasal mahar politik dalam UU Pemilu tidak mengandung ketentuan pidana sebagaimana aturan mahar politik dalam Pasal 47 juncto Pasal 187B dan 187C UU Pilkada (Putusan DKPP, 2019). Oleh karena itu, Bawaslu kemudian menilai dalam kajian akhir bahwa kasus tersebut tidak dapat ditindaklanjuti karena tidak terbukti secara hukum, sehingga secara yuridis tidak memenuhi unsur pelanggaran pemilu. Atas hasil kajian ini, pelapor (Seteven G. Tunas) tidak puas dan kemudian mengadukan Bawaslu kepada Dewan Kehormatan Penyelenggara Pemilu (DKPP) atas dugaan pelanggaran kode etik penyelenggara pemilu. Atas laporan tersebut, maka pada tanggal 2 Januari 2019, DKPP mengeluarkan putusan dengan Nomor: 233/DKPPPKE-VII/2018 untuk menjatuhkan sanksi peringatan kepada Bawaslu, karena dinilai melanggar Pasal 11 huruf $b$, huruf $c$, huruf d, dan Pasal 15 huruf e Peraturan DKPP Nomor 2 Tahun 2017 tentang Kode Etik dan Pedoman Perilaku Penyelenggara Pemilihan Umum. Adapun pertimbangan DKPP ialah, bahwa frasa "tidak terbukti atau belum ditemukan cukup bukti" dalam hasil kajian akhir Bawaslu, perlu dilakukan kajian secara materiil dan lebih mendalam dalam penggunaannya (bukan perihal semantik semata). Selain itu, Bawaslu seharusnya melakukan upaya lebih jauh untuk menghadirkan Andi Arief sebagai saksi utama dalam kasus mahar politik tersebut.

Dalam konteks ini, Bawaslu yang diberi amanah sebagai lembaga dalam mengawasi penyelenggaraan Pemilu di seluruh Indonesia (Pasal 1 angka 17 UU Pemilu) perlu menjadikan penegakan hukum mahar politik sebagai salah satu perhatian serius dalam menangani pelanggaran pemilu. Dalam menangani tindak pidana pemilu tersebut, Bawaslu dibantu oleh Sentra Penegakan Hukum Terpadu (Gakkumdu) yang berfungsi sebagai forum koordinasi antara Internal Bawaslu, Kepolisian RI, serta Kejaksaan RI dalam penegakan hukum pemilu 
(Pasal 486 ayat (1) UU Pemilu). Karena jika merujuk pada data Bawaslu, hingga November 2019 terdapat sekitar 20.999 laporan dan temuan dugaan pelanggaran pemilu (Bawaslu, 2019). Sekitar 16.423 merupakan pelanggaran administrasi dan 2.798 kasus termasuk pidana pemilu. Dari hasil penanganan pelanggaran, Bawaslu memutuskan 16.134 sebagai pelanggaran administrasi, 582 telah diproses secara pidana, serta 1 kasus terkait mahar politik berhasil diproses oleh Bawaslu. Meskipun demikian, satu kasus mahar politik tersebut masih menyisakan kebenaran materiil yang belum secara utuh dapat diungkap. Padahal akar pokok masalah pemilu di Indonesia, salah satunya berasal dari praktik tindak pidana mahar politik (Taher, 2018).

Adapun salah satu kendala dalam mengungkap mahar politik: Pertama, kasus tersebut tersimpan rapat di internal partai dan tidak akan muncul ke permukaan publik, sebelum ada salah satu pihak yang dikecewakan. Karena pada dasarnya, sifat dasar mahar politik ialah simbiosis mutualisme (saling menguntungkan) antara parpol dengan sosok yang akan diusung. Kedua, merupakan isu liar yang sumir dicari kebenaran buktinya. Bahwa oknum itu nyata adanya, namun sangat susah ditelusuri keberadannya. Karena seringkali pihak yang melemparkan isu adanya dugaan mahar politik seringkali tidak dapat diklarifikasi untuk memberikan keterangan lebih lanjut. Akibatnya, proses klarifikasi bisa jadi hanya dilakukan melalui keterangan pihak lain (testimonium de auditu). Sehingga kasus tersebut hanya menjadi isu atau bola panas yang berkeliaran, yang tidak memiliki kekuatan pembuktian, serta tidak jelas ujungnya.

\subsection{Politik Hukum Pidana Terhadap Mahar Politik di Indonesia}

Untuk menjawab rumusan ini, teori Friedman (1986) terkait sistem hukum akan dielaborasikan dengan kerangka berfikir politik hukum dalam memformulasikan norma serta penegakan hukum tindak pidana mahar politik di Indonesia kedepan. Menurut Friedman, dalam memahami hukum sekaligus penegakan hukum tidak bisa hanya dipahami aspek norma hukumnya saja. Perlu ada pemahaman sistem hukum yang menyeluruh sebagai satu kesatuan sistem, baik substansi hukum, struktur hukum, dan kultur hukum.

\section{- Substansi Hukum}

Pertama, pentingnya pendekatan hukum pidana dalam pengaturan sanksi tindak pidana mahar politik. Kerangka hukum dan sanksi terhadap pelanggaran tindak pidana pemilu merupakan aturan dasar International Electoral Standards yang harus dipenuhi dalam undangundang (International IDEA, 2002). Dalam konteks ini, UU Pemilu hanya mengatur sanksi yang bersifat administratif terhadap pelanggaran tindak pidana mahar politik (penerima). Sementara bagi pemberi hanya diatur norma larangan tanpa ada sanksi apapun (Pasal 228 ayat (4)). Namun dalam UU Pilkada, pelaku mahar politik justru dijerat dengan sanksi administratif, denda, sekaligus pidana (Pasal 47, 187B, 187C).

Jika ditelusuri dalam risalah sidang pembahasan RUU Pemilu, isu sanksi mahar politik bukan termasuk dalam 15 isu krusial dalam penyusunan substansi RUU Pemilu. Dari 67 kali rapat pembasan RUU Pemilu, isu presidential threshold selalu menjadi perhatian utama serta 
pembahasan paling alot di DPR (DPR RI, 2017). Namun dalam naskah akademik RUU Pemilu, justru ditegaskan bahwa rumusan pidana terkait pemilu perlu dijabarkan secara komprehensif guna menyesuaikan dengan perkembangan hukum, misal perluasan subjek dan sanksinya (Kemendagri, 2016).

Menurut Maria Farida Indrati, bahwa perumusan aturan sanksi (pidana) dalam undang-undang merupakan ketentuan yang tidak mutlak (Indrati, 2007). Artinya tergantung pada masing-masing rumusan. Namun menurut ketentuan Pasal 5 UU. No. 12 Tahun 2011 tentang Pembentukan Peraturan Perundang-undangan (PUU), bahwa dikenal asas kejelasan tujuan dan kejelasan rumusan. Selain itu, dalam Pasal 6 ayat (1) PUU tercantum asas ketertiban dan kepastian hukum. Sehingga, meskipun sanksi pidana bersifat tidak mutlak, tetapi sanksi tersebut relatif sangat diperlukan guna pemenuhan terhadap asas-asas dalam pembentukan hukum terkait pemilu.

Pada dasarnya, efektivitas sanksi pelanggaran pemilu tidak bisa hanya diukur dari kategori sanksi tertentu. Tetapi secara teoritis, hukum pidana merupakan sanksi pamungkas (ultimum remidium) dalam penegakan hukum (Bemmelen, 1984). Namun tingginya tingkat kecenderungan penggunaan sanksi pidana dari pemilu ke pemilu, ternyata tidak juga cukup efektif menekan pelanggaran pemilu (Santoso, 2014). Kekhawatiran yang muncul bahwa penggunaan sanksi pidana hanya mengikuti kecenderungan peraturan terdahulu, tanpa dilakukan kajian yang mendalam tentang efektivitas aturan pidana tersebut.Karena tidak sedikit norma yang sebetulnya cukup sanksi administratif, tanpa diancam sanksi pidana. Namun disisi lain, penggunaan sanksi administratif juga belum tentu menjadi pilihan yang paling tepat dalam mengatasi pelanggaran pemilu.

Bertalian dengan itu, Wirjono Prodjodikoro berpendapat bahwa norma atau kaidah hukum tata negara atau hukum tata usaha negara pertamatama harus ditanggapi dengan sanksi administratif, namun jika sanksi tersebut belum mencapai tujuan neraca kemasyarakatan, maka sanksi pidana harus digunakan untuk lebih memperkuat agar norma tersebut dapat dipatuhi (Prodjodikoro, 2003). Dengan kata lain, penggunaan sanksi pidana juga berperan untuk melindungi norma yang sudah ada sebelumnya, khususnya sanksi administratif mahar politik dalam pemilu. Jika dikaji lebih lanjut, ternyata tindakan pemberian mahar kepada partai politik bisa dikatakan jauh dari konteks administrasi pemilu, bahkan tindakan tersebut justru cenderung hampir serupa dengan tindakan pemberian uang (money politics) atau tindakan suap atau gratifikasi yang kesemuanya merupakan tindakan pidana murni. Disisi yang lain, pentingnya sanksi pidana mahar politik dalam UU Pemilu juga semakin diperkuat dengan tindakan koordinasi antara Bawaslu dengan Bareskrim Polri dalam penanganan dugaan pemberian mahar politik oleh Sandiaga Uno. Padahal dalam UU Pemilu secara tegas tidak disebutkan sanksi pidana. Namun, Bawaslu masih berupaya untuk menginterpretasi sanksi pidana mahar politik UU Pilkada untuk dikorelasikan dengan UU Pemilu. Dengan kata lain, tindakan Bawaslu justru semakin membuka ruang pentingnya rumusan sanksi pidana mahar politik dalam UU Pemilu kedepan, baik dirumuskan secara 
kumulatif atau bersifat alternatif dengan sanksi lainnya.

Kedua, perlu merumuskan dengan jelas batasan perbedaan frasa imbalan, sumbangan dana kampanye, serta dana saksi. Meskipun hampir sebagian besar partai politik menolak adanya istilah mahar politik dilekatkan pada partainya, namun Indonesia Corruption Watch menilai bahwa dana mahar diduga terus mengalir dengan kamuflase dana atau biaya saksi (Fatmawati, 2018). Terminologi imbalan diatur dalam pasal 228 UU Pemilu, sumbangan dana kampanye dalam pasal 327 UU Pemilu, sementara dana saksi tidak ditemukan pengaturannya dalam undang-undang. Sehingga, rumusan diantara ketiga terminologi tersebut harus diperjelas definisi dan aturannya, karena hal tersebut sangat erat kaitannya dengan mahar politik.

\section{- Struktur Hukum}

Dalam konteks pemilu, entitas struktur hukum tersebut tentu tidak terlepas dari KPU, Bawaslu, serta DKPP. Bahkan dalam konteks penegakan hukum pidana pemilu, juga meliputi kepolisian dan kejaksaan dalam wadah Gakkumdu. Hadirnya anggota kepolisian, kejaksaan, dan internal Bawaslu dalam satu komposisi Gakkumdu tersebut, harus dapat bekerjasama dengan baik, serta harus bebas dari konflik kepentingan (ego sektoral) antar lembaga. Untuk menjamin itu, maka Bawaslu dalam komposisi Gakkumdu harus mempunyai peranan yang lebih dominan dalam mengambil keputusan penegakan hukum tindak pidana terkait pemilu.

Bertalian dengan itu, koordinasi antara penyelenggara pemilu dan para penegak hukum lainnya perlu ditingkatkan. Sebab kompleksitas permasalahan dalam pemilu, menjadikan Bawaslu tidak bisa hanya bekerja sendirian tanpa bantuan dari semua elemen penting suksesnya pemilu. Sehingga fungsi koordinasi menjadi sangat penting, agar semua elemen tersebut berjalan beriringan dalam mensukseskan pelaksanaan pemilu. Selain itu, Bawaslu juga perlu untuk meningkatkan kesadaran sosial, efektifitas, efisiensi kelembagaan, kesadaran organisasi, integritas, keberanian dan ketegasan, kepercayaan diri, serta jiwa kepemimpinan harus dimiliki oleh personal sumber daya Bawaslu, karena hal tersebut sangat membantu dalam meningkatkan performa dalam kelembagaan Bawaslu.

Bertalian dengan penegakan hukum tindak pidana mahar politik, Bawaslu perlu membuat strategi khusus untuk mengatasi persoalan tersebut. Hal itu dapat dimulai dengan membuat kesepahaman tujuan bahwa mahar politik merupakan persoalan pokok dari pelanggaran pidana pemilu. Kemudian perlu dibentuk sentra pengaduan khusus bagi peserta pemilu yang menjadi korban mahar politik, misalnya di inisiasi oleh Gakkumdu. Karena dari wadah tersebut penyelidikan terkait mahar politik bisa dikembangkan lebih lanjut. Selain itu, aparat penegak hukum harus terlibat aktif dalam menyisir praktik mahar politik. Karena jika hanya menunggu laporan (korban), akan sangat terbatas untuk memperoleh informasi. Sebab dalam sebagian kasus, terdapat korban yang tidak bersedia melapor karena juga takut terjerat pidana. Dalam konteks ini, penegak hukum harus jeli untuk mendapatkan bukti yang relevan atau meminta keterangan dari pihak lain yang juga mengetahui praktik tersebut. 


\section{- Budaya Hukum}

Kaitannya dengan budaya hukum pemilu di Indonesia, beberapa hal penting harus menjadi perhatian serius dalam merumuskan politik hukum pidana dalam penegakan hukum mahar politik. Salah satunya menghilangkan budaya politik uang. Praktek ini hampir mendominasi setiap lini pengisian posisi jabatan politik, jabatan non-politik, dan jabatan publik lainnya. Suburnya budaya ini, juga tidak terlepas dari cara pandang masyarakat yang permisif terhadap politik uang, yang telah dianggap sebagai budaya dalam berpolitik. Akibatnya ongkos politik menjadi mahal dan kepemimpinan diukur dari modal. Budaya ini sangat merugikan masyarakat serta dapat mereduksi nilainilai demokrasi.

Upaya tersebut dapat dilakukan melalui reformasi sistem pembiayaan pemilu serta menetapkan tujuan politik (political goals) dalam pembiayaan pemilu (Ballington, 2014). Sistem pembiayaan partai politik yang jelas, diharapkan dapat memunculkan pemimpian yang ideal naik ke permukaan publik, tanpa harus dibebani dengan syarat mahar politik. Lahirnya pemimpin tersebut kiranya mampu menjadi pemimpin yang transfomatif dalam mengaktualisasikan karakter pemimpin yang memiliki sikap kenegarawanan dan karakter kepemimpinan konstitusional yang demokratis dan inspiratif di Indonesia.

\section{Simpulan}

Munculnya kasus mahar politik dalam setiap pelaksanaan pemilu di Indonesia, tentu tidak terlepas dari karakter politik hukum UU Pemilu dalam suatu negara. Lemahnya regulasi, tidak jelasnya rumusan pasal mengenai subjek, objek, sanksi, serta rendahnya komitmen aparat penegak hukum untuk mengusut tuntas problem mahar politik, justru hanya menjadikan kasus tersebut sebagai isu musiman yang tidak jelas ujungnya, bahkan hampir tidak pernah terungkap kepada publik.

Oleh sebab itu, ditengah kompleksitas persoalan mahar politik tersebut (Pilpres 2019), kedepan diperlukan pendekatan politik hukum pidana dalam penegakan hukumnya. Dengan kata lain, penegakan hukum mahar politik tersebut tidak bisa hanya dimaknai dengan penegakan undang - undang atau revisi rumusan, aturan, dan sanksi hukumnya saja. Namun juga perlu ada pemahaman hukum yang menyeluruh sebagai satu kesatuan sistem, yakni penegakan substansi hukum, struktur, serta kulturnya. Hal tersebut, juga sejalan dengan konsep politik hukum pidana yang dikemukakan oleh Sudarto (2007), yakni merumuskan ulang perbuatan dan sanksi (substansi), serta prosedur penegakan hukumnya (substansi, struktur, dan kultur). Sehingga, politik hukum pidana yang harus dibangun dalam penegakan hukum mahar politik kedepan ialah merumuskan frasa mahar politik, melekatkan sanksi pidana (alternatif atau kumulatif) dalam UU Pemilu, menguatkan kelembagaan Bawaslu dalam penanganan tindak pidana pemilu, serta menghilangkan budaya politik uang dengan upaya reformasi sistem pembiayaan pemilu di Indonesia. 


\section{DAFTAR PUSTAKA}

Arief, B.N. (1992). Bahan Bacaan Politik Hukum Pidana. Jakarta: Pascasarjana Universitas Indonesia.

Azra, A. (2016, Maret 03). Mahar Politik, Politik Mahar. Kompas.com. Diakses dari https://nasional.kompas.com/read/2016/03/16/10594231/Mahar.Politik. Politik.Mahar?page=all.

Ballington, J. dkk. (2014). Getting the Political Finance System Right. Dalam E. Falguera., S. Jones., \& M. Ohman. (Eds). Funding of Plitical Parties and Eletion Campaign: A Handbook on Political Finance (hlm.33-34). Stockholm, Sweden: International IDEA.

Bawaslu. (2019, November 05). Update Data Pelanggaran Pemilu Tahun 2019 per 4 November 2019. Bawaslu. Diakses dari https://www.bawaslu.go.id/id/ hasil-pengawasan-pemilu/update-data-pelanggaran-pemilu-tahun-2019-4november-2019.

Bawaslu. (2018). Indeks Kerawanan Pemilu 2019. Jakarta: Badan Pengawas Pemilihan Umum Republik Indonesia.

Bemmelen, J.M.V. (1984). Hukum Pidana 1: Hukum Pidana Material Bagian Umum. Bandung: Binacipta.

Chambliss, W.J. \& Siedman, R.B. (1971). Law, Order, and Power. Reading, Mass, Massachusetts: Addison-Wesley Publishing Company.

DPR RI. (2017). Risalah Resmi Rapat Paripurna Dewan Perwakilan Rakyat Republik Indonesia Masa Persidangan Ke-V Tahun Sidang 2016-2017. Jakarta: Dewan Perwakilan Rakyat Republik Indonesia.

Dalilah, E., dkk. (2018). Benturan Kepentingan pada Pendanaan Pilkada. Jurnal Antikorupsi Integritas, Vol. 5, No. 1, hlm. 181-188.

Fatmawati, N.I. (2018, Januari 16). ICW: Mahar Politik Kerap Dikamuflase Jadi Biaya Saksi. Detik.com. Diakses dari https://news.detik.com/berita/d-3817765/icwmahar-politik-kerap-dikamuflase-jadi-biaya-saksi.

Friedman, L.M. (1986). The Legal System: A Social Science Perspective. New York: Russel Sage Foundation.

Galanter, M. (1974). Why The 'Have' Come Out Ahead: Speculations on The Limits of Legal Change. Law and Society Review, Vol. 9, No. 1, hlm. 95-160.

Hamdan, M. (1999). Politik Hukum Pidana. Jakarta: PT Raja Grafindo Persada.

Hoefnagels, G.P. (1973). The Other Side of Criminology: An Inversion of The Concept of Crime. New York: Springer Bussines Media.

Indrati, M.F. (2007). IImu Perundang-Undangan: Proses dan Teknik Pembentukannya. Yogyakarta: Kanisius.

International IDEA. (2002). International Electoral Standards: Guidelines for Reviewing the Legal Framework of Elections. Stockholm: International IDEA.

Kemendagri. (2016). Naskah Akademik Rancangan Undang-Undang tentang 
Penyelenggaraan Pemilihan Umum. Jakarta: Kementerian Dalam Negeri Republik Indonesia.

Karana. (2018, Februari 06). Kasus Dugaan Mahar Politik Pilkada Palangkaraya Dihentikan. Tempo. Diakses dari https://pilkada.tempo.co/read/1057960/ kasus-dugaan-mahar-politik-pilkada-palangkaraya-dihentikan/full\&view=ok. Marzuki, P.M. (2012). Pengantar Ilmu Hukum. Jakarta: Kencana Persada.

Mahfud, M.D. (2012). Politik Hukum di Indonesia. Jakarta: PT. Raja Grafindo Persada. Nainggolan, Y. dkk. (2018). Sengkarut Mahar Politik dalam Pemilu di Indonesia. Dalam

A.T. Muchtar (Ed). Update Indonesia: Tinjauan Bulanan Ekonomi, Hukum, Keamanan, Politik, dan Sosial (hlm. 16-18). Jakarta, Indonesia: The Indonesia Institute Centre for Public Policy Research.

Nugraheny, D.E. (2018, Februari 16). Bawaslu Hentikan Kasus Dugaan Mahar Politik La Nyalla. Republika. Diakses dari https://www.republika.co.id/berita/nasional/ pilkada /18/02/16/p47not335-bawaslu-hentikan-kasus-dugaan-mahar-politikla-nyalla.

Peraturan Badan Pengawas Pemilihan Umum (Bawaslu) Republik Indonesia Nomor 7 Tahun 2018 tentang Penanganan Temuan dan Laporan Pelanggaran Pemilihan Umum.

Peraturan Dewan Kehormatan Penyelenggara Pemilu (DKPP) Republik Indonesia Nomor 2 Tahun 2017 tentang Kode Etik dan Pedoman Perilaku Penyelenggara Pemilihan Umum.

Prodjodikoro, W. (2003). Asas-Asas Hukum Pidana di Indonesia. Bandung: Refika Aditama.

Putusan Dewan Kehormatan Penyelenggara Pemilu (DKPP) Republik Indonesia Nomor: 233/DKPP-PKE-VII/2018 tentang Dugaan Pelanggaran Kode Etik Penyelenggara Pemilihan Umum. Diputuskan dalam Rapat Pleno pada 02 Januari 2019 dan Dibacakan dalam Sidang Kode Etik Terbuka untuk Umum pada 16 Januari 2019. Rahmanto, T.Y. (2019). Penegakan Hukum Terhadap Tindak Pidana Penipuan Berbasis Transaksi Elektronik. Jurnal Penelitian Hukum De Jure, Vol. 19, No. 1, hlm. 31-52.

Rahardjo, S. (2009). Penegakan Hukum, Suatu Tinjauan Sosiologis. Yogyakarta: Genta Publishing.

Rahardjo, S. (1996). Ilmu Hukum. Bandung: Citra Aditya Bakti.

Roihanah, R. (2015). Penegakan Hukum di Indoensia: Sebuah Harapan dan Kenyataan. Justitia Islamica, Vol. 12, No. 1, hlm. 40-52.

Santoso, T. (2014). Peranan Hukum Pidana dalam Proses Demokrasi. Depok: Fakultas Hukum Universitas Indonesia.

Sudarto. (2007). Hukum dan Hukum Pidana. Bandung: Penerbit Alumni.

Sudarto. (1986). Kapita Selekta Hukum Pidana. Bandung: Penerbit Alumni.

Taher, A.P. (2018, Januari 18). Mengapa Sulit Mengungkap Praktik Mahar Politik di Pilkada?. Tirto.id. Diakses dari https://tirto.id/mengapa-sulit-mengungkappraktik-mahar-politik-di-pilkada-cDpu.

Utama, A. (2018, Januari 12). Mahar Politik untuk Partai di Indonesia, Antara Ada dan 
Tiada. BBC. Diakses dari https://www.bbc.com/indonesia/indonesia-42664437 Undang-Undang Dasar Negara Republik Indonesia Tahun 1945.

Undang-Undang Nomor 7 Tahun 2017 tentang Pemilihan Umum (Lembaran Negara Republik Indonesia Tahun 2017 Nomor 182, Tambahan Lembaran Negara Republik Indonesia Nomor 6109).

Undang-Undang Nomor 10 Tahun 2016 tentang Perubahan Kedua atas Undang-Undang Nomor 1 Tahun 2015 tentang Penetapan Peraturan Pemerintah Pengganti Undang-Undang Nomor 1 Tahun 2014 tentang Pemilihan Gubernur, Bupati, dan Walikota Menjadi Undang-Undang (Lembaran Negara Republik Indonesia Tahun 2016 Nomor 130, Tambahan Lembaran Negara Republik Indonesia Nomor 5898).

Undang-Undang Nomor 12 Tahun 2011 tentang Pembentukan Peraturan PerundangUndangan (Lembaran Negara Republik Indonesia Tahun 2011 Nomor 82, Tambahan Lembaran Negara Republik Indonesia Nomor 5234).

Vionita, L.A. \& Khasanah, U. (2018). Analisis Hukum Pidana terhadap Praktik Mahar Politik. Al-Jinayah: Jurnal Hukum Pidana Islam, Vol. 4, No. 2, hlm. 204-219. Yusfitriadi. (2018). Audit Dana Kampanye Pilkada Serentak 2015 di Indonesia: Studi Kasus di 11 Kabupaten/Kota. Dalam M. Sukmajati dan A. Perdana (Ed). Pembiayaan Pemilu di Indonesia (203-223). Jakarta, Indonesia: Badan Pengawas Pemilihan Umum Republik Indonesia. 